\title{
Antarctic ice-shelf calving triggered by the Honshu (Japan) earthquake and tsunami, March 2011
}

\author{
Kelly M. BRUNT, ${ }^{1}$ Emile A. OKAL, ${ }^{2}$ Douglas R. MacAYEAL ${ }^{3}$ \\ ${ }^{1}$ NASA Goddard Space Flight Center/GESTAR, Code 614.1, Greenbelt, Maryland 20771, USA \\ E-mail: kelly.m.brunt@nasa.gov \\ ${ }^{2}$ Department of Earth \& Planetary Sciences, Northwestern University, 1850 Campus Drive, Evanston, Illinois 60201, USA \\ ${ }^{3}$ Department of Geophysical Sciences, University of Chicago, 5734 South Ellis Avenue, Chicago, Illinois 60637, USA
}

\begin{abstract}
We use European Space Agency Envisat data to present the first observational evidence that a Northern Hemisphere tsunami triggered Antarctic ice-shelf calving more than $13000 \mathrm{~km}$ away. The Honshu tsunami of 11 March 2011 traversed the Pacific Ocean in $<18$ hours where it impinged on the Sulzberger Ice Shelf, resulting in the calving of $125 \mathrm{~km}^{2}$ of ice from a shelf front that had previously been stable for $>46$ years. This event further illustrates the growing evidence of ocean-wave impact on Antarctic calving and emphasizes the teleconnection between the Antarctic ice sheet and events as far away as the Northern Hemisphere.
\end{abstract}

\section{INTRODUCTION}

The Honshu earthquake of 11 March 2011, centered $130 \mathrm{~km}$ off the east coast of Sendai, Japan $\left(38.32^{\circ} \mathrm{N}, 142.37^{\circ} \mathrm{E}\right.$; $32 \mathrm{~km}$ depth), triggered a tsunami that propagated across the Pacific and Southern Oceans, reaching Antarctica within 1822 hours (US National Oceanic and Atmospheric Administration (NOAA)/Pacific Marine Environmental Laboratory (PMEL)/Center for Tsunami Research; http://nctr.pmel.noaa. gov/). Models of the tsunami predicted an amplitude of $\sim 30 \mathrm{~cm}$ in the open Southern Ocean (NOAA/PMEL/Center for Tsunami Research). As the tsunami interacted with the bathymetry of the Pacific Ocean basin, reflected and refracted waves added to the complexity of wave arrivals along the coast of Antarctica that persisted for days. For example, at Cape Roberts $\left(77.0^{\circ} \mathrm{S}, 163.7^{\circ} \mathrm{E}\right)$ in the western Ross Sea, Antarctica (Fig. 1), the record from a tide gauge maintained by Land Information New Zealand (Fig. 2) shows the arrival of the tsunami. The NOAA models of peak amplitude of the tsunami at Cape Roberts are on the order of $20 \mathrm{~cm}$; its following train of dispersed waves took $\sim 72$ hours to dissipate below the amplitude of swell associated with local storm events (http://www.linz.govt.nz/).

Holdsworth and Glynn (1978) suggested that iceberg calving from ice shelves and glacier tongues could be due to fatigue associated with repeated flexure caused by the impact of ocean waves of various types. They proposed that given sufficient energy within an appropriate frequency band, ocean swell could resonantly excite the gravest modes of coupled gravity-wave/elastic-flexure vibration in the floating ice, which could in turn lead to calving. This connection between iceberg calving and the surface gravitywave environment of the ocean is further motivated by observations and model studies of the effects of tsunamis, tides and swell along the calving margin of the Ross Ice Shelf (MacAyeal and others, 2006; Okal and MacAyeal, 2006; Arbic and others, 2008; Cathles and others, 2009; Bromirski and others, 2010; Brunt and others, 2010; Sergienko, 2010). MacAyeal and others (2006) went so far as to suggest that the arrival of long-period swell from a storm in the North Pacific precipitated the break-up of a large $\sim 800 \mathrm{~km}^{2}$ iceberg (B15A) in shoaling waters off Cape Adare, Antarctica, in 2005. Martin and others (2010) subsequently reassessed the circumstances of the break-up of B15A to conclude that the interaction between the iceberg and a seabed shoal was the likely cause of the break-up, rather than the simultaneous arrival of swell. Nevertheless, the observed effects of swell on a seismograph deployed on B15A at the time of break-up reported by MacAyeal and others (2006) indicate that sea swell is still a strong factor in stimulating the iceberg's motions in the 100-10 s period range. This iceberg had, in fact, also been influenced by the effects of earthquakes and tsunamis in a notable manner prior to its break-up. The $M=8.4$ earthquake off the coast of Peru on 23 June 2001 produced a tsunami that may have caused B15A to remobilize after becoming jammed in its drift trajectory (personal communication from C. Stearns, 2002; fig. 11 of MacAyeal and others, 2008); however, it remains unclear whether this mobilization was the result of the tsunami or of the arrival of surface seismic waves (e.g. Rayleigh waves) that may have induced resonant bobbing of the iceberg.

Following the gigantic Arica earthquake and tsunami of 13 August 1868, Solov'ev and Go (1984) list a report of the observation by the Chilean Navy, a few weeks later, of unseasonably abundant, freshly cut icebergs drifting in the Southern Ocean, which could have been calved off an Antarctic ice shelf by the Arica tsunami. Given the strength of the tsunami associated with the recent tragic earthquake off Japan, it is natural to assess the possibility that this event caused calving or other forms of ice-shelf and iceberg disturbance along the coast of Antarctica. To evaluate this possibility, we turn our attention to the Sulzberger Ice Shelf (SIS; $76.53^{\circ} \mathrm{S}, 150.16^{\circ} \mathrm{W}$ ), which is just east of the Ross Ice Shelf (Fig. 1), along the part of the Antarctic coast where models suggest that the tsunami likely had large amplitude (NOAA/PMEL/Center for Tsunami Research; http:// nctr.pmel.noaa.gov/). This ice shelf is $160 \mathrm{~km}$ wide at its calving front and is $100 \mathrm{~km}$ long from its inland grounding line to its ice front. Because it fringes a rugged mountainous section of the Antarctic continent, the SIS is one of the slowest-moving ice shelves in Marie Byrd Land (Ferrigno and others, 2004). It is riddled with numerous islands and ice rises, where ice-shelf flow is interrupted and where ice-flow suture zones are formed providing lines of weakness along which iceberg detachment fractures are likely to occur. 


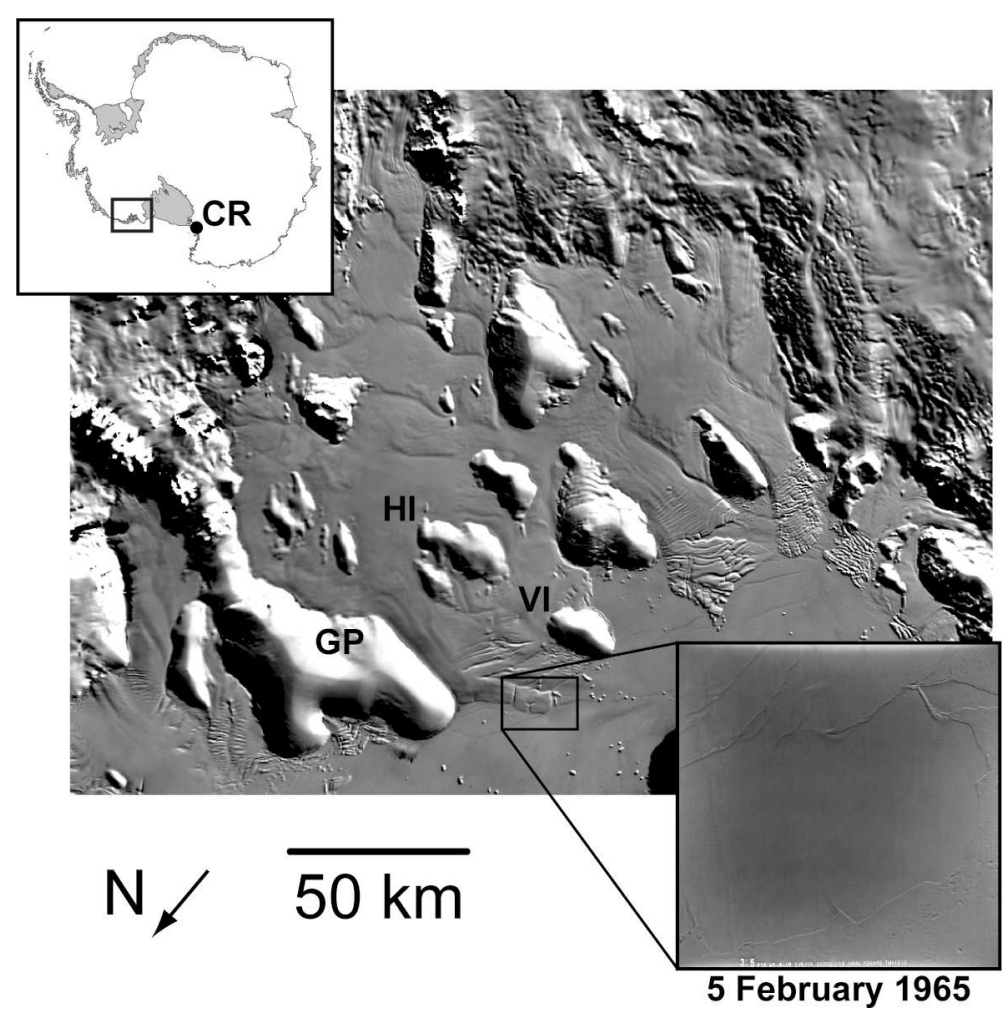

Fig. 1. The Sulzberger Ice Shelf, Antarctica. Moderate Resolution Imaging Spectroradiometer (MODIS) mosaic image (Scambos and others, 2007). Cape Roberts (CR; upper inset), Guest Peninsula (GP), Hutchinson Island (HI) and Vollmer Island (VI) are indicated. Lower inset is a trimetrogon aerial photograph (5 February 1965) from USGS US Antarctic Resource Center and the Polar Geospatial Center.

On the eastern edge of the ice shelf, between Vollmer Island and Guest Peninsula, the ice front is relatively thin ( $<80 \mathrm{~m}$; Le Brocq and others, 2010) and slow or possibly stagnant $\left(<0.1 \mathrm{~m} \mathrm{a}^{-1}\right.$; Ferrigno and others, 2004). Additionally, this region is dominated by rifting, which is associated specifically with the suture zone of the ice flowing around Hutchinson Island to the south. The depth of the ocean in front of the ice shelf is $\sim 150 \mathrm{~m}$. However, within only $100 \mathrm{~km}$ of the ice-shelf front, the depth of the water column increases to over $800 \mathrm{~m}$ (Le Brocq and others, 2010).

Until March 2011, this section of the ice-shelf front included a rectangular $10 \mathrm{~km} \times 6 \mathrm{~km}$ region of ice that was defined on two sides by rifts that had formed at the Hutchinson Island suture zone. One rift was longitudinal to flow while the other was transverse to flow. The other two sides were open to the Southern Ocean. While this rift-bound region of ice seemed prime to calve, it was considerably stable and has been seen as a coherent section of the iceshelf front in trimetrogon aerial photography dating back to 5 February 1965 (Fig. 1; United States Geological Survey
(USGS) US Antarctic Resource Center; Polar Geospatial Center). Analysis of repeat-track laser altimeter data from the NASA Ice, Cloud and land Elevation Satellite (ICESat) also indicates that between February 2004 and March 2007 the rate of advection of rift features matched the low ice-flow velocities of Ferrigno and others (2004), which were based on a comparison of Landsat (from 1976 and 1986) and RADARSAT (from 1997) imagery. The 1965 USGS imagery suggests that the shape of the ice-shelf front has been stable for 46 years. Additionally, the Landsat, RADARSAT and ICESat data suggest that the velocity of the ice shelf in this region has not undergone dynamic changes, which would have contributed to calving, in the past 35 years.

\section{OBSERVATIONS}

The Honshu earthquake occurred on 11 March 2011 at 05.46.23 UTC (USGS Earthquake Hazards Program). Based on the coordinates for the SIS, the Rayleigh seismic surface waves should have reached the Guest Peninsula $13600 \mathrm{~km}$

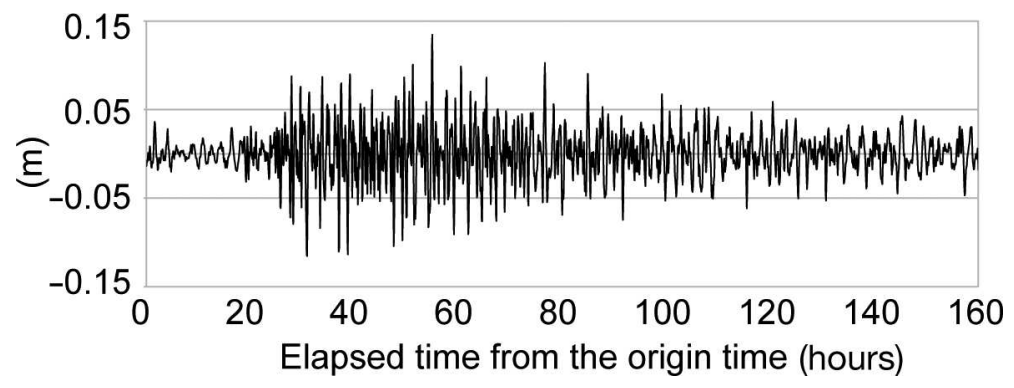

Fig. 2. Tsunami record ( $\mathrm{m}$ of sea-surface elevation) from Cape Roberts, Antarctica, bandpass filtered (0.0001-0.001 Hz). The origin of the time axis is the Honshu earthquake. 
away by $\sim 06.45$ UTC. Factoring in the depth of the water column and a detoured path around New Zealand, the tsunami should have reached this region by $\sim 00.00$ UTC on 12 March 2011, 18.3 hours after origin time.

Examination of a series of the NASA Moderate Resolution Imaging Spectroradiometer (MODIS) Rapid Response images (http://rapidfire.sci.gsfc.nasa.gov/) indicated that on 13 March 2011 at 00.00 UTC the $10 \mathrm{~km} \times 6 \mathrm{~km}$ rift-bounded section of ice, adjacent to Guest Peninsula, had calved from the SIS. Resolution of the MODIS imagery $(250 \mathrm{~m})$, and cloud cover in both previous and subsequent images, compromised efforts to create an informative time series of the MODIS imagery.

Fortunately, however, a series of European Space Agency (ESA) Envisat advanced synthetic aperture radar (ASAR) images (Rott and others, 2007) between 11 and 13 March 2011 (Fig. 3) confirm the calving event first observed in the MODIS imagery and allow it to be constrained in time to a period consistent with the arrival of the tsunami. A time series of these $30 \mathrm{~m}$ resolution georeferenced images (available for download through Polar View: http://www. polarview.aq) indicates that the calving event included more of the ice-shelf front than just the $10 \mathrm{~km} \times 6 \mathrm{~km}$ iceberg observed in the MODIS imagery. It also shows mobilization of ice floes and small icebergs that were previously static along the calving margin of the SIS.

From the first two images in the ASAR series (Fig. 3), the front of the SIS remains unchanged immediately following the earthquake. After the expected arrival time of the Honshu tsunami (12 March 2011, 00.00 UTC), calving of the $10 \mathrm{~km} \times 6 \mathrm{~km}$ iceberg is evident in the first available image, which was taken slightly less than 12 hours after the tsunami's arrival (12 March, 11.52 UTC).

On 13 March, two additional ASAR images show the obvious separation of the second, slightly smaller iceberg $(7 \mathrm{~km} \times 4 \mathrm{~km})$, which calved from the region adjacent to the western edge of the first iceberg. The total area of the SIS lost to this calving event, including the two measurable icebergs and smaller iceberg bits, was slightly in excess of $125 \mathrm{~km}^{2}$.

\section{DISCUSSION AND SUMMARY}

The Honshu tsunami, acting as a trigger for the calving of the SIS, is indeed consistent with available observations of the ice and with models of tsunami propagation and amplitude. However, we make note of two other factors that also may have enabled the tsunami to act as this trigger: the glaciological conditions of the ice shelf and the sea-ice conditions immediately adjacent to the ice-shelf front.

Glaciologically, the bulk of the section of the front of the SIS that calved as a result of the Honshu earthquake was a $10 \mathrm{~km} \times 6 \mathrm{~km}$ rift-bound block that had been stable (based on USGS trimetrogon aerial photography) for at least 46 years. The second, smaller iceberg created during this calving event was also from the heavily rifted region associated with the Hutchinson Island suture zone. Rifts are structural flaws within the ice that are precursors to the detachment fractures that accompany calving (Fricker and others, 2002). As such, large sections of the front of both the Ross and Amery Ice Shelves, which are at least partially defined by rifts, have acquired names that suggest that calving is imminent: 'Nascent Iceberg' (Brunt and others, 2010) and 'Loose Tooth' (Bassis and others, 2005), respectively. However, these

\section{Time (UTC)}
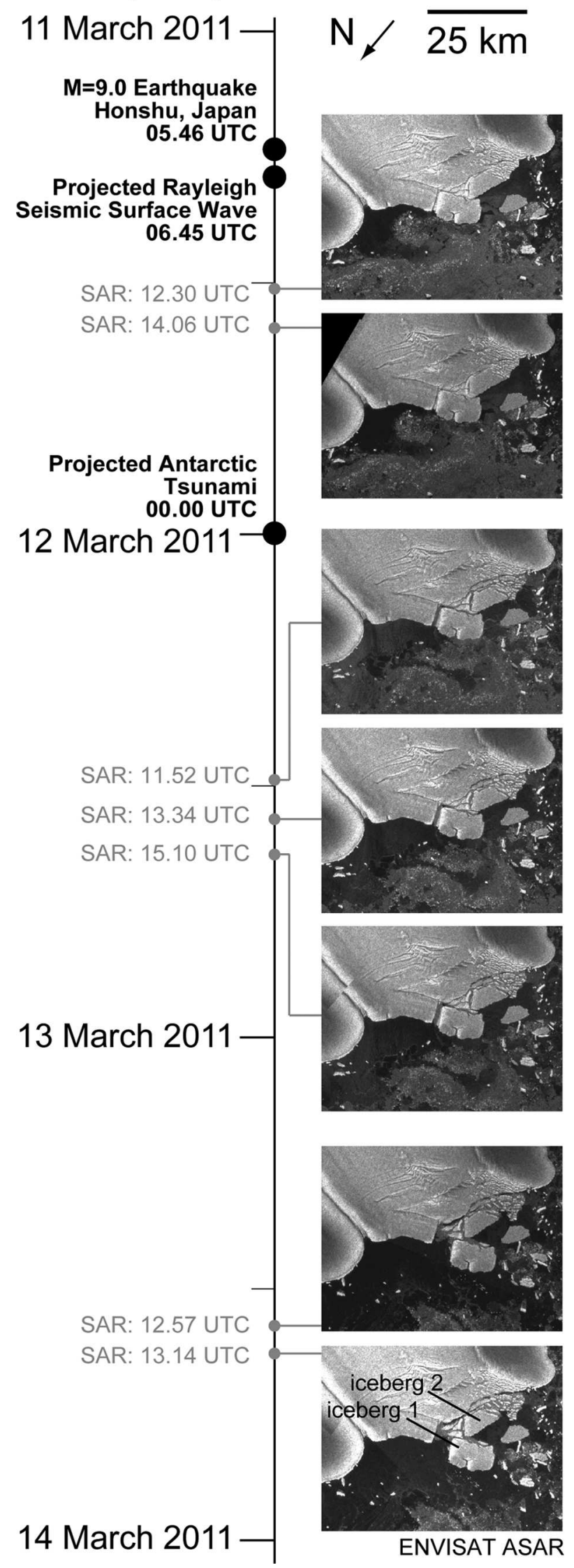

Fig. 3. Timeline of the SIS calving event of March 2011. Timing of the Honshu earthquake and the projected SIS arrivals of the Rayleigh seismic surface waves and the tsunami are indicated by the black dots. Timing of the ESA Envisat ASAR images is indicated by the grey dots. The last image indicates the two sizable icebergs (iceberg 1: $10 \mathrm{~km} \times 6 \mathrm{~km}$; iceberg 2: $7 \mathrm{~km} \times 4 \mathrm{~km}$ ). 
seemingly fragile regions of the ice-shelf front have remained connected with their respective ice shelves for longer than predicted (Bassis and others, 2005) and have notably survived several tsunamis, including the most recent one from Japan. The recent calving from the SIS suggests that, while the rifts provide the ice-shelf front with a zone that is weakened with respect to stress, and while tsunamis arrive episodically to cause vibrational disturbances to these rifts, some additional enabling condition must be satisfied before a given tsunami can lead to the detachment of an iceberg.

The timing of the earthquake and tsunami in Japan coincided with the typical summer sea-ice minimum (Zwally and others, 2002). As observed in the MODIS imagery and confirmed in the ASAR imagery, the region north of the SIS was devoid of either fast or pack ice at the time of predicted arrival of the tsunami. Fast ice is an important factor in iceshelf stability (Massom and others, 2010). Additionally, the absence of sea ice meant that the energy associated with the tsunami incident on the ice-shelf front was not damped by sea-ice flexure. With a distant tsunami source, over an irregular ocean bathymetry, and taking into account the dispersion of high-frequency components of the tsunami outside the shallow-water approximation, a complex pattern of dispersed waves is predicted in the wake of the leading front of the tsunami (NOAA/PMEL/Center for Tsunami Research; http://nctr.pmel.noaa.gov). As these waves interacted with the ice shelf over a period of hours to days, flexural modes may have been resonantly excited, each with the potential to trigger iceberg calving (Holdsworth and Glynn, 1978), in a pattern reminiscent of the delayed response of harbors documented in the far field during the 2004 Sumatra tsunami (Okal and others, 2006).

This study presents the first observational evidence linking a tsunami to ice-shelf calving. Specifically, the impact of the tsunami and its train of following dispersed waves on the SIS, in combination with the ice-shelf and seaice conditions, provided the fracture mechanism needed to trigger the first calving event from the ice shelf in 46 years. This observation adds to the mounting evidence that environmental and tectonic conditions in the far field, including the Northern Hemisphere, can have an important role in defining Antarctic ice-shelf stability.

\section{ACKNOWLEDGEMENTS}

Support was provided by US National Science Foundation grant ANT-0944193 and ANT-0944233. We thank P. Morin at the University of Minnesota Polar Geospatial Center for providing rapid access to digital satellite imagery, and J. Bassis at the University of Michigan for continued discussion on the causes of iceberg calving.

\section{REFERENCES}

Arbic, B.K., J.X. Mitrovica, D.R. MacAyeal and G.A. Milne. 2008. On the factors behind large Labrador Sea tides during the last glacial cycle and the potential implications for Heinrich events. Paleoceanography, 23(3), PA3211. (10.1029/2007PA001573.)

Bassis, J.N., R. Coleman, H.A. Fricker and J.B. Minster. 2005. Episodic propagation of a rift on the Amery Ice Shelf, East
Antarctica. Geophys. Res. Lett., 32(6), L06502. (10.1029/ 2004GL022048.)

Bromirski, P.D., O.V. Sergienko and D.R. MacAyeal. 2010. Transoceanic infragravity waves impacting Antarctic ice shelves. Geophys. Res. Lett., 37(2), L02502. (10.1029/2009GL041488.)

Brunt, K.M., M.A. King, H.A. Fricker and D.R. MacAyeal. 2010. Flow of the Ross Ice Shelf, Antarctica, is modulated by the ocean tide. J. Glaciol., 56(195), 157-161.

Cathles, L.M., E.A. Okal and D.R. MacAyeal. 2009. Seismic observations of sea swell on the floating Ross Ice Shelf, Antarctica. J. Geophys. Res., 114(F2), F02015. (10.1029/ 2007JF000934.)

Ferrigno, J.G., R.S. Williams, Jr and K.M. Foley. 2004. Coastalchange and glaciological map of the Saunders Coast area, Antarctica, 1972-1997. Ann. Glaciol., 39, 245-250.

Fricker, H.A., N.W. Young, I. Allison and R. Coleman. 2002. Iceberg calving from the Amery Ice Shelf, East Antarctica. Ann. Glaciol., 34, 241-246.

Holdsworth, G. and J.E. Glynn. 1978. Iceberg calving from floating glaciers by a vibrating mechanism. Nature, 274(5670), 464-466.

Le Brocq, A.M., A.J. Payne and A. Vieli. 2010. An improved Antarctic dataset for high resolution numerical ice sheet models (ALBMAP v1). Earth Syst. Sci. Data, 2(2), 247-260.

MacAyeal, D.R. and 13 others. 2006. Transoceanic wave propagation links iceberg calving margins of Antarctica with storms in tropics and Northern Hemisphere. Geophys. Res. Lett., 33(17), L17502. (10.1029/2006GL027235.)

MacAyeal, D.R., M.H. Okal, J.E. Thom, K.M. Brunt, Y.-J. Kim and A.K. Bliss. 2008. Tabular iceberg collisions within the coastal regime. J. Glaciol., 54(185), 371-386.

Martin, S. and 6 others. 2010. Kinematic and seismic analysis of giant tabular iceberg breakup at Cape Adare, Antarctica. J. Geophys. Res., 115(B6), B06311. (10.1029/2009JB006700.)

Massom, R.A. and 7 others. 2010. Examining the interaction between multi-year landfast sea ice and the Mertz Glacier Tongue, East Antarctica: another factor in ice sheet stability? J. Geophys. Res., 115(C12), C12027. (10.1029/2009JC006083.)

Okal, E.A. and D.R. MacAyeal. 2006. Seismic recording on drifting icebergs: catching seismic waves, tsunamis and storms from Sumatra and elsewhere. Seismol. Res. Lett., 77(6), 659-671.

Okal, E.A., H.M. Fritz, R. Raveloson, G. Joelson, P. Pančošková and G. Rambolamanana. 2006. Madagascar field survey after the December 2004 Indian Ocean tsunami. Earthquake Spectra, 22(S3), S263-S283.

Rott, H., W. Rack and T. Nagler. 2007. Increased export of grounded ice after the collapse of Northern Larsen Ice Shelf, Antarctic Peninsula, observed by Envisat ASAR. In Lacoste, H. and L. Ouwehand, eds. IGARSS '07, International Geoscience and Remote Sensing Symposium, 23-27 July 2007, Barcelona, Spain. Proceedings, Vol. 3. Piscataway, NJ, Institute of Electrical and Electronics Engineers, 673-675.

Scambos, T.A., T.M. Haran, M.A. Fahnestock, T.H. Painter and J. Bohlander. 2007. MODIS-based Mosaic of Antarctica (MOA) data sets: continent-wide surface morphology and snow grain size. Remote Sens. Environ., 111(2-3), 242-257.

Sergienko, O.V. 2010. Elastic response of floating glacier ice to impact of long-period ocean waves. J. Geophys. Res., 115(F4), F04028. (10.1029/2010JF001721.)

Solov'ev, S.L. and Ch.N. Go. 1984. Catalogue of tsunamis on the eastern shore of the Pacific Ocean. Sidney, B.C., Institute of Ocean Sciences. Department of Fisheries and Oceans. (Canadian Translation of Fisheries and Aquatic Sciences 5078.)

Zwally, H.J., J.C. Comiso, C.L. Parkinson, D.J. Cavalieri and P. Gloersen. 2002. Variability of Antarctic sea ice 1979-1998. J. Geophys. Res., 107(C5), 3041. (10.1029/2000JC000733.) 